\title{
The use of lasers in restorative dentistry: truths and myths
}

O uso de laseres na odontologia restauradora:

verdades e mitos

Carolina STEINER-OLIVEIRA

Post-doctoral researcher - FAPESP - Special Laboratory of Lasers in Dentistry -Restorative Department - School of Dentistry - University of São Paulo - São Paulo - Brazil.

Karen Müller RAMALHO

$\mathrm{PhD}$ - Department of Stomatology - Integrated Clinic - School of Dentistry - University of São Paulo - São Paulo - Brazil.

Marina Stella BELLO-SILVA

$\mathrm{PhD}$ - Post-Graduate Program in Biophotonics Applied to Health Sciences - Nove de Julho University - São Paulo - Brazil.

Ana Cecília Corrêa ARANHA

Professor - Special Laboratory of Lasers in Dentistry - Restorative Department - School of Dentistry - University of São Paulo - São Paulo - Brazil.

Carlos de Paula EDUARDO

Full professor - Special Laboratory of Lasers in Dentistry Restorative Department - School of Dentistry - University of São Paulo - São Paulo - Brazil.

\begin{abstract}
Researchers have been investigating the clinical applications of lasers in dentistry, which can be operated in high and low intensity. The high intensity lasers work with increasing temperature for ablation, vaporization, cutting and coagulating of the tissue while the low level lasers therapy are used in the photophysical, photobiological and photochemical effects on the cells of the irradiated tissues. This review approaches the use of lasers of high and low intensity focused in restorative dentistry. The indications for high power lasers are for dental erosion treatment, in the reconstitution of the canine guides, in the final removal of carious tissue, for dentin hypersensitivity, for microbial reduction, in the conditioning of enamel and dentin for adhesive systems and for caries prevention in pits and fissures. The low power laser can be used after cavity preparation in order to reduce post-operative sensitivity, in aesthetic procedures for maintaining periodontal health and also in the photodynamic therapy, which provides microbial reduction, combining a photosensitizing agent to a light source.
\end{abstract}

\section{KEYWORDS}

Lasers; Dentistry; Operative; Anti-inflammatory agents; P hotodynamic therapy; Ablation techniques.

\section{Resumo}

Pesquisadores têm investigado as aplicações clínicas dos laseres na odontologia, que podem ser operados em alta e baixa intensidade. Os laseres de alta intensidade têm ação com o aumento da temperatura propiciando a ablação, a vaporização, o corte e a coagulação dos tecidos enquanto que a fototerapia com laser em baixa intensidade é utilizada para se obter efeitos fotofísicos, fotobiológicos e fotoquímicos sobre as células dos tecidos irradiados. Esta revisão aborda o uso de laseres em alta e baixa intensidade, focado na odontologia restauradora. As indicações para os laseres de alta potência incluem o tratamento da erosão dentária, a reconstituição dos guias caninos, a remoção final de tecido cariado, a redução microbiana, o condicionamento do esmalte e dentina para uso dos sistemas adesivos e a prevenção de cárie em sulcos e fissuras. Os laseres em baixa potência podem ser utilizados após o preparo da cavidade, a fim de reduzir a sensibilidade pós-operatória, em procedimentos estéticos para a manutenção da saúde periodontal e também na terapia fotodinâmica, que proporciona uma redução microbiana, combinando um agente de fotossensibilização a uma fonte de luz.

\section{Palavras-chave}

Laser; Odontologia restauradora; Agentes antiinflamatórios; Terapia fotodinâmica; Técnicas de ablação. 


\section{INTRODUCTION}

Since the development of the first LASER (Light Amplification by acronym of the Estimulated Emission of Radiation) by Maiman in 1960, researchers have investigated the clinical applications of lasers in dentistry, which can be classified into high and low intensity. The high intensity lasers treatment (HILT) are intended for ablation, vaporization cutting and coagulating of the tissue because they work with increasing temperature, while the low intensity lasers (LLLT) are used in the processes of tissue repair, inflammation and in cases in which analgesia is required. This latter therapy is based on the use of low irradiance that influence cell behavior, it is not thermal, which means that their biological effects are not caused by heat or noticeable cell damage; it works by photophysical, photobiological and photochemical effects on the cells of the irradiated tissues [1].

The LLLT used in clinical dentistry operate in the visible range of the electromagnetic spectrum, more precisely in the range of red light wavelength (approximately 600-700 nm) and near-infrared range (up to approximately $1000 \mathrm{~nm}$ ) [2]. Among them we can mention the He-Ne laser (Helium Neon) and diode lasers. Among the HILT, we can highlight the laser Nd:YAG (Neodymium), $\mathrm{CO}_{2}$, Er:YAG (Erbium), Er,Cr: YSGG (ErbiumChromium) and high power diodes.

The way the laser will interact with tissue will depend on the optical characteristics of the laser used (wavelength, power, exposure time, energy, etc.) as well as on the optical characteristics of the target tissue (chromophores present in the tissue, depth of structure being treated, body fat percentage, etc.) [3].

Particularly in restorative dentistry, there are many indications for high power lasers; for example, in dental erosions, in reconstitution of the canine guides, final removal of carious tissue (with the benefit to the conservative dentistry), in dentin hypersensitivity, in microbial reduction, the conditioning of enamel and dentin for adhesive systems [4,5], internal conditioning of prosthetic ceramic pieces, prior to permanent luting (lasers Er: YAG and Er, Cr: YSGG) [6] and caries prevention in pits and fissures. The low power laser can be used after cavity preparation in order to reduce post-operative sensitivity and microbial reduction after cavity preparation, combining a photosensitizing agent to low power laser or LED (photodynamic therapy); also, in aesthetic procedures in maintaining periodontal health [7-9].

\section{Critical review}

\section{Truths}

\section{Enamel conditioning}

Since the $60 \mathrm{~s}$, several studies on the effects of laser in dental mineralized tissues have been conducted. The widespread use of lasers in science is promoting advances in restorative dentistry and particularly in Dental Aesthetics. In this context, the application of this technology in the selective removal of carious tissue and preparation of tooth surface for adhesive restorative procedures can be mentioned.

Among the various wavelengths available, the Er: YAG $(2.94 \mu \mathrm{m})$ and the Er,Cr: YSGG lasers $(2.78 \mu \mathrm{m})$ stand out as having high affinity for hydroxyl ions present in water molecules and hydroxyapatite, thus being effectively absorbed by dental hard tissues[10,11]. The use of the Er:YAG and Er,Cr:YSGG lasers for cavity preparation was approved by Food and Drug Administration (FDA) in 1997 and 1998, respectively [12,13]. Several studies in the literature indicate the TEA $\mathrm{CO}_{2}$ laser (Transversely Excitated Atmospheric Pressure) as a promising equipment for the ablation of dental hard tissues [14-16]. These lasers emit at wavelengths of 9.6 e $10.6 \mu \mathrm{m}$, and are effectively absorbed by phosphate groups present in the hydroxyapatite [17]. Despite the positive results reported for conservative cavity preparation $[15,16,18]$, the TEA $\mathrm{CO}_{2}$ laser is still not commercialized, and is only available to laboratory studies or restricted use in clinical trials.

Depending on parameters used and tissues targeted, high power lasers can promote dental surface conditioning or even remove dental hard tissues [1921]. The difference in composition of mineralized dental tissues results in lower ablation threshold for dentin compared to enamel, since the former has a higher organic content [10]. In other words, ablation of dentin requires lower energy densities when compared to enamel.

Irradiation of dental enamel with erbium lasers produces a morphological pattern resultant from the ablation process, with exposition/removal of prisms [10,22,23]. The surface topography 
presents a micro retentive pattern that provides micro retention of adhesive restoration to dental substrate $[24,25]$. Although the effects of lasers on enamel are still discussed in the literature, several studies evaluating the quality of the adhesion between irradiated enamel and restorative materials show positive results [26-30]. One example of the use of high power lasers for enamel conditioning is the restoration of worn teeth for re-establishing dentition function and recovering esthetics. Enamel conditioning with Er:YAG laser followed by restoration with composite resin provides resistant and long-lasting outcomes, even in presence of intense occlusal stress [31].

Unlike irradiated enamel, for which studies show favorable results regarding adhesion, bonding to irradiated dentin is still considered controversial in the literature. Although irradiation of dentin with erbium laser lead to increased surface roughness, with the presence of open dentinal tubules [32-34], no demineralization or exposition of collagen fribils for penetration of resin monomers is observed [35].

Considering the clinical use of erbium lasers for enamel conditioning, studies indicate that both efficiency and feasibility in daily practice can be achieved, without prejudice to the pulp tissues and with great acceptance by patients due to reduction of vibration and noise, reduction of pain sensitivity and, in some cases, no need for using anesthetics [36-38]. Moreover, one of the main advantages of high power lasers is its antimicrobial action. Due to the increase of temperature, ablation of dental hard tissue is accompanied by microbial reduction of adjacent tissues, contributing to a better prognosis when this technology is associated with the treatment [39].

\section{LLLT applied in gingival cares during aesthetics proceedings}

Currently there are numerous new technologies to improve dental treatments. The low intensity laser therapy (LLLT) was established as a noninvasive method to enhance chronic wound healing, modulate inflammatory process and promote pain relief [40-44]. In Restorative dentistry, the health of gingiva is mandatory for the success of all clinical steps [45]. During the indirect restorative treatment, correct hygiene must be performed by patients; otherwise, inflammation will occur in gingival tissue. If inflammation occurs, the restorative treatment should be paused until the gingiva gets healthy [45].
The LLLT has shown satisfactory results as a complementary alternative therapy to achieve a healthy gingiva. In the recovery of healthy gingiva, LLLT will act through its anti-inflammatory and biomodulatory effect. The anti-inflammatory and anti-edema effect of LLLT occurs, due to several outcomes, as increase in microcirculation, resulting in alteration in hydrostatic pressure in vasculature, with edema resorption [46] and modulation of molecules as PGE2, COX-2 and Interleukins $[40,43]$. The LLLT has shown significant effect in tissue regeneration, an important tool in gingiva reparation.

The table below (Table 1) summarizes some studies concerning the anti-inflammatory and biomodulatory effects of LLLT related to tissue healing.

\section{TABLE 1 - IN VITRO FINDINGS OF LLLT EFFECTS ON TISSUE}

\begin{tabular}{l|l}
\hline Effects & Author \\
\hline $\begin{array}{l}\text { Increase in fibroblasts and } \\
\text { epithelial cell proliferation }\end{array}$ & $\begin{array}{l}\text { Walsh, 1997 [47]; Almeida- } \\
\text { Lopes et al., 2001 [48]; Pereira } \\
\text { et al., 2002 [49]; Azevedo et al., } \\
\text { 2006 [50]; Saygun et al., 2008 } \\
\text { [51]. }\end{array}$ \\
\hline $\begin{array}{l}\text { Increase in leucocytes } \\
\text { phagocytosis }\end{array}$ & Walsh, 1997 [47] \\
\hline $\begin{array}{l}\text { Increase in endothelial celll } \\
\text { proliferation }\end{array}$ & Walsh, 1997 [47] \\
\hline $\begin{array}{l}\text { Increase in myofibroblasts } \\
\text { differentiation }\end{array}$ & $\begin{array}{l}\text { Pourreau-Schneider et al., } \\
1990 \text { [52] }\end{array}$ \\
\hline $\begin{array}{l}\text { Increase in ascorbic acid } \\
\text { levels in fibroblasts, leading } \\
\text { to increase in hydroxyproline, } \\
\text { and collagen synthesis. }\end{array}$ & Walsh, 1997 [47] \\
\hline $\begin{array}{l}\text { Biostimulation of cytoskeleton } \\
\text { proteins, leading to higher } \\
\text { stability from lipoproteic layer } \\
\text { in cellular membrane }\end{array}$ & Walsh, 1997 [47] \\
\hline $\begin{array}{l}\text { Increase in } \\
\text { neovascularization }\end{array}$ & \\
\hline $\begin{array}{l}\text { Increase in growth factors, as } \\
\text { bFGF, IGF-1 }\end{array}$ & Walsh, 1997 [47]; Saygun et \\
\hline $\begin{array}{l}\text { Inhibition in Prostaglandin E } \\
\text { e Interleukin 1- } \beta\end{array}$ & $\begin{array}{l}\text { Shimizu et al., 1995 [40]; } \\
\text { Sakurai et al., 2000 [43] }\end{array}$ \\
\hline
\end{tabular}

Some recent clinical studies confirmed the results found in other in vitro studies and showed that LLLT is an efficient additional tool for the conventional treatment of gingival inflammation and has shown satisfactory outcome in the control and maintenance of a healthy gingiva. Table 2 summarizes these clinical studies. 


\section{Table 2 - Clinical Studies using laser as a tool for gingival health ReCOVery}

\begin{tabular}{l|l}
\hline $\begin{array}{l}\text { Qadri et al., } 2005 \\
\text { [7] }\end{array}$ & $\begin{array}{l}\text { Evaluated } 17 \text { patients submitted to periodontal treatment. In the lased group (1x/week during } 6 \mathrm{weeks} ; 635 \mathrm{~nm} ; 10 \\
\left.\mathrm{~mW} ; 90 \mathrm{~s} ; 9 \mathrm{~J} ; 4.5 \mathrm{~J} / \mathrm{cm}^{2} ; 50 \mathrm{~mW} / \mathrm{cm}^{2} ; \text { and } 830 \mathrm{~nm} ; 70 \mathrm{~mW} ; 25 \mathrm{~s} ; 1.75 \mathrm{~J} ; 8.75 \mathrm{~J} / \mathrm{cm}^{2} ; 350 \mathrm{~mW}^{2} / \mathrm{cm}^{2} ;\right) \text { a significant } \\
\text { positive result was found. There was a significant periodontal pocked depth reduction and gingivitis level reduction. } \\
\text { A decrease in the crevicular fluid was also described, as well as the reduction of MMP8 (metalloproteinase 8) }\end{array}$ \\
\hline $\begin{array}{l}\text { [Pejcic and Grujicic, } \\
2007[8]\end{array}$ & $\begin{array}{l}\text { performed in their clinical study, histological analysis from the gingival tissue removed from } 15 \text { patients that were } \\
\text { submitted to conventional periodontal treatment and also conventional treatment associated with LLLT (1 session/ } \\
\text { day during } 5 \text { days - } 670 \mathrm{~nm} ; 4-15 \mathrm{~mW} ; 2 \mathrm{~min} ; 100-200 \mathrm{~mW} / \mathrm{cm}^{2} \text { ). The analysis showed that in the irradiated tissue } \\
\text { there were complete regeneration and less inflammatory cells when compared to the group submitted only to } \\
\text { conventional treatment. The irradiated tissue also showed better collagen fibers organization. The authors concluded } \\
\text { that LLLT, when associated to conventional treatment is effective in inflammation reduction. }\end{array}$ \\
\hline [Pejcic et al., 2010 \\
[9] & $\begin{array}{l}\text { Evaluated LLLT (10 sessions - } 670 \mathrm{~nm} ; 150 \mathrm{~mW} / \mathrm{cm}{ }^{2} ; \text { or } 18 \mathrm{~J} / \mathrm{cm}^{2} \text { ) associated with conventional periodontal } \\
\text { treatment in } 30 \text { patients with gingival inflammation. The results have shown that these patients had less plaque, } \\
\text { less gingival index and less gingival bleeding in all the follow-up periods: } 1,3 \text { and } 6 \text { months. Interestingly, in all the } \\
\text { periods, the LLLT results obtained were maintained, differently from the control groups (conventional periodontal } \\
\text { treatment), where some recurrences from the gingival inflammation occurred. The authors concluded that LLLT } \\
\text { is an additional tool to periodontal treatment that presents long lasting satisfactory results in the management of } \\
\text { gingival inflammation. }\end{array}$ \\
\hline
\end{tabular}

It's important to point out that LLLT has shown positive results when applied as a therapy. This means that only one application has not shown beneficial results. It must be applied in several sessions[7-9].

\section{LLLT applied after cavity preparation}

Regularly, patients relate a post-operative pain after cavity preparation for both direct and indirect restorations. Restorative procedures can be a source of injury to the pulp tissue and can occur due to several factors, such as heat generated during cavity preparation, the method of restorative material placement, among others [54-55]. To prevent sensitivity, small pellets of composites should be inserted into the cavity to avoid polymerization shrinkage and materials should be biocompatible with the tissue [56].

The dental pulp of human teeth is profusely innervated [57]. Fearnhead (1957) [58] have shown that small nerve fibrils with an approximate diameter of $0.2 \mu \mathrm{m}$ were in close relationship with the odontoblast process extending as far as $1.5 \mathrm{~mm}$ into the dentin. Consequently, stimulus applied during the restorative procedure will be captured by the pulp though this system. Brännström et al (1960) [60] has provided evidence that the main cause of dentinal pain is a rapid outward flow of fluid in the dentinal tubules, which is initiated by capillary forces. Temperature was found to have a great effect on the hydraulic conductance of dentin. Increasing the temperature by $40^{\circ} \mathrm{C}$ resulted in a 1.8 fold increase in fluid flow in unetched dentin and in a 4 folds increase in acidetched dentin. Therefore, a high temperature increase occurring in a dental treatment will lead to stimuli transmitted to the pulp, and sensitivity will certainly develop. Dentists should take special care to prevent inducing high temperatures in etched dentin.

The literature has demonstrated several advantages of the use of low intensity lasers in restorative dentistry though in vivo studies. Godoy et al., (2007) [55] used a laser wavelength of $670 \mathrm{~nm} ; 30 \mathrm{~mW}$ and $2 \mathrm{~J} / \mathrm{cm}^{2}$, applied directly and perpendicularly in Class I cavities in premolars in a single visit, and restored the teeth with composite resin. After 28 days the teeth were extracted and transmission electron microscopy analysis showed that the lased groups presented the odontoblast process in greater contact with the extracellular matrix and the collagen fibrils appeared more aggregated and organized than those of the control group. It was concluded that laser irradiation accelerated the recovery of dental structures involved in cavity preparation in the pre-dentin region. Ferreira et al., (2006) [60] used a $670 \mathrm{~nm}$ laser wavelength; $50 \mathrm{~mW}$ and $4 \mathrm{~J} / \mathrm{cm}^{2}$ in Class V cavities in premolars, and after this, performed restorations with glass ionomer. The teeth were extracted after 14 and 42 days. Histological changes were observed by light microscopy; less intense inflammatory reaction was found in the irradiated group when compared with the control group. Only in the group of teeth extracted 42 days after laser application, an area associated with reactionary dentinogenesis was shown. The immunohistochemical analysis also revealed that expression of Collagen type III, Tenascin and Fibronectin was greater in the irradiated group.

The inflammatory modulation capacity of LLLT has been proved by several studies [40,43,61]. LLLT can also show beneficial effects on pain control [62-64]. All the beneficial effects of LLLT, such as pain control, inflammatory and reparative tissue modulation can 
bring advantages to restorative procedures, helping in pulp tissue recovery as well as providing patients with comfortable post-operative condition.

It can be concluded that LLLT can bring several advantages to restorative dentistry after cavity preparation as a co-adjuvant in conventional treatment. Nonetheless, dentists should not forget the factors that induce tissue damage, such as the use of old burs that induce abrasion and excessive heat increase during cavity preparation, the restorative material placement method, chemical irritants among others, and must control them to prevent post-operative sensitivity.

\section{The status of laser in erosion prevention}

Tooth wear is becoming increasingly significant [65]. The tooth surface loss due to dental erosion refers to the pathological loss of tissue without the involvement of bacteria. Dental erosion may be caused by a series of extrinsic and intrinsic factors [66]. Extrinsic factors largely include the consumption of acidic foods and carbon $\neg$ ated beverages, sports drinks, red and white wines, citrus fruits and, to a lesser degree, occupational exposure to acidic environments [65]. Soft drink consumption in the USA increased by $300 \%$ in 20 years [67]. Nowadays there is a consensus that four or more acid intake per day are associated with high risk of dental erosion [68]. The most common intrinsic fac - tors include chronic gastro-intestinal disorders such as gastro-esophageal disease as well as health issues like anorexia and bulimia, where regurgitation and frequent vomiting are common $[65,69,70]$.

The strategies to control erosive tooth wear include the early diagnosis of hard tissue defects and the evaluation of the different etiological factors to identify persons athigh risk [71]. The elimination of the causative factors may be difficult, since they are associated to habits or lifestyle, and depend on nutritional, medical, psychological and professional factors, that predispose individual to dental erosion. Erosive lesions frequently require preventive and restorative treatments [72]. However, restorative procedures do not prevent further progression of erosive/abrasive wear [73].

Researchers have been focused in finding new methods for dental erosion prevention. The possibility of increasing the enamel resistance to demineralization after laser irradiation was first demonstrated in 1965 with a ruby laser [74]. Over time and with the increasing knowledge about the interaction of laser with dental hard tissues, other wavelengths were tested.

As research methodologies used to study high intensity lasers in erosion prevention varies among them, concerning laser wavelengths, dosage, pulse width, erosion challenges, etc, it's not possible to compare the results between the studies. Some studies showed partial beneficial results with Nd:YAG lasers [75-79].

Carbon dioxie lasers have been mostly tested in erosion prevention among other wavelengths, due to its efficient interaction with hydroxyapatite [8084]. Depending on the parameters used some studies showed complete or partial negative effect of $\mathrm{CO}_{2}$ laser in erosion prevention [85-88], as well as others studies showed positive results [89-91].

The erosion preventive effect of $\mathrm{CO}_{2}$ laser with the parameters: $10.6 \mu \mathrm{m}, 0.3 \mathrm{~J} / \mathrm{cm}^{2}, 5 \mu \mathrm{s}, 226 \mathrm{~Hz}$, have been confirmed by several studies with different erosion challenges [89-91].

In situ studies are also very important concerning dental erosion, once some modified biological factors presented in oral cavity, such as saliva, regulate the progression of the disease. The single in situ study with $\mathrm{CO}_{2}$ laser on the topic of laser and erosion, confirm the positive result of $\mathrm{CO}_{2}$ laser, taking account the biological modifying factors in the results [92].

In conclusion, based on the published researches, $\mathrm{CO}_{2}$ laser when applied with the wavelength of $10.6 \mu \mathrm{m}$, low energy density $\left(0.3 \mathrm{~J} / \mathrm{cm}^{2}\right)$, and short pulse width (5 $\mu \mathrm{s})$, seems to be a promising tool in the prevention of tooth erosive wear. Nevertheless it's important to point out that this parameter is not available at the moment in any clinical laser equipment.

\section{Pits and fissures cleaning}

Occlusal surfaces are more susceptible to caries attacks and have been responsible for $84 \%$ of caries lesions in 5-17-years-old children Council on Access, Prevention and Interprofessional Relations [93]. Several explanations may be proposed, such as constant biofilm formation on this tooth surface, $\mathrm{pH}$ fluctuations stemming from metabolic processes within these films, [94] immaturity of the tooth substances, when they are recent irrupted in the oral cavity, [95] the lower diffusion of the fluoride ion in the deepest regions of the crevice minimizing the effect of this ion upon caries progression [96] and difficulties in oral hygiene due to the posterior position of the molars in the dental arch. A delay in recession of the operculum eventually leads to an accumulation of plaque that is inaccessible to a toothbrush and reduces the chance of effective and timely application of caries preventive measures such as fissure sealants and fluoride therapy [97].

The use of laser for the prevention of dental caries is based on the reduction of microorganisms [98-99], due to its action on the dental plaque, chemical [100-103] and morphological modification of the enamel structure [103- 
105] turning them more resistant to acid demineralizing.

Several high power lasers - $\mathrm{CO}_{2}$, Er:YAG and $\mathrm{Nd}$ :YAG have been tested with the purpose of treating the pit and fissure surfaces [100,106-112]. Some characteristics and the main findings of some researches are shown in Table 3.

\section{Table 3 - Findings of the HILT on pit and fissure treatments}

\begin{tabular}{|c|c|c|}
\hline $\begin{array}{l}\text { Laser type and } \\
\text { parameters }\end{array}$ & Effects & Author \\
\hline $\begin{array}{l}\mathrm{CO}_{2} \text { laser, } 10.6 \\
\mu \mathrm{m}, 2-5 \mathrm{~W}\end{array}$ & $\begin{array}{l}\text { Physicochemical alterations } \\
\text { in enamel which may have } \\
\text { preventive benefits for sealing } \\
\text { pits and fissures }\end{array}$ & $\begin{array}{l}\text { Walsh } \\
\text { and } \\
\text { Perham, } \\
1991[106]\end{array}$ \\
\hline Nd-YAG laser & $\begin{array}{l}\text { Nd-YAG laser irradiation was } \\
\text { effective in increasing the acid } \\
\text { resistance of the pit and fissure } \\
\text { enamel, while removing the pit } \\
\text { and fissure debris contents and } \\
\text { increasing the fluoride uptake } \\
\text { into the pit and fissure enamel. }\end{array}$ & $\begin{array}{l}\text { Bahar and } \\
\text { Tagomori, } \\
1994 \text { [100] }\end{array}$ \\
\hline $\begin{array}{l}\mathrm{CO}_{2} \text { laser, } 10.2 \\
\mathrm{~W} \text {, pulsing } \\
\text { emission at } 7 \\
\text { pps and pulsing } \\
\text { and } 20 \mathrm{msec}\end{array}$ & $\begin{array}{l}\text { Occlusal caries prevention } \\
\text { with } \mathrm{CO}_{2} \text { laser only was not } \\
\text { effective; When associated } \\
\text { with photoactivated sealants, } \\
\text { effective preventive action; } \\
\text { irradiation of } \mathrm{CO}_{2} \text { laser over } \\
\text { occlusal fissures, prior to the } \\
\text { application of a photoactivated } \\
\text { fissure sealants, improved their } \\
\text { retention. }\end{array}$ & $\begin{array}{l}\text { Brugnera } \\
\text { Jr. et al., } \\
1997[107]\end{array}$ \\
\hline $\begin{array}{l}\text { Nd:YAG, } 2.0 \\
\mathrm{~W}, 20 \mathrm{~Hz} \text { and } \\
124.3 \mathrm{~J} / \mathrm{cm}^{2} \text { for } \\
3 \text { minutes }\end{array}$ & $\begin{array}{l}\text { In shallow fissures, the sealing } \\
\text { was total but in narrow and } \\
\text { deep fissures, the sealing was } \\
\text { partial or incomplete. }\end{array}$ & $\begin{array}{l}\text { Myaki et } \\
\text { al., } 1998 \\
{[108]}\end{array}$ \\
\hline $\begin{array}{l}\text { Er:YAG laser, } \\
\text { handpiece } \\
2051 \text {, water } \\
\text { spray-cooled, } \\
200 \mathrm{~mJ}, 2 \mathrm{~Hz} \\
\text { handpiece } 2055 \\
\text { with a quartz } \\
\text { fiberoptic } 50 / 10 \text {, } \\
\text { air cooled, } 350 \\
\mathrm{~mJ}, 2 \mathrm{~Hz} \text { and } \\
400 \mathrm{~mJ}, 2 \mathrm{~Hz}\end{array}$ & $\begin{array}{l}\text { Morphological changes } \\
\text { suggesting that the irradiation } \\
\text { by Er:YAG laser produced } \\
\text { melting and recrystallization of } \\
\text { the enamel fissures }\end{array}$ & $\begin{array}{l}\text { Matson et } \\
\text { al., 2002 } \\
{[109]}\end{array}$ \\
\hline $\begin{array}{l}\mathrm{CO}_{2} \text { laser, } 9.6 \\
\mu \mathrm{m}, 2.0 \text { or } 3.0 \\
\mathrm{~J} / \mathrm{cm}^{2} \\
5-8 \mu \text { in pulse } \\
\text { duration }\end{array}$ & $\begin{array}{l}\text { Percentage of caries inhibition } \\
\text { progression with laser and/or } F \\
\text { ranged from } 87-170 \%\end{array}$ & $\begin{array}{l}\text { Nobre dos } \\
\text { Santos, } \\
2002 \text { [110] }\end{array}$ \\
\hline $\begin{array}{l}\mathrm{CO}_{2} \text { laser, } 10.6 \\
\mu \mathrm{m}, 0.3 \text { watt; } 10 \\
\mathrm{msec} ; 15 \mathrm{~Hz} \\
\text { energy density, } \\
15 \mathrm{~J}^{\mathrm{cm}}{ }^{2}\end{array}$ & $\begin{array}{l}\text { Effective treatment in the } \\
\text { prevention of pit and fissure } \\
\text { caries in partially erupted } \\
\text { permanent molars covered with } \\
\text { opercula }\end{array}$ & $\begin{array}{l}\text { Kato, } \\
2003 \text { [111] }\end{array}$ \\
\hline $\begin{array}{l}\text { Er:YAG - } 80 \mathrm{~mJ} \\
2 \mathrm{~Hz} ; \\
\mathrm{Nd}: Y A G \text { Laser - } \\
1 \mathrm{~W}, 10 \mathrm{~Hz} \\
\mathrm{CO} \text { Laser - } 0.4 \\
\text { W, } 20 \mathrm{~Hz}\end{array}$ & $\begin{array}{l}\mathrm{CO}_{2} \text { laser should be selected } \\
\text { in order to increase the enamel } \\
\text { resistance to acid in pits and } \\
\text { fissures }\end{array}$ & $\begin{array}{l}\text { Correa- } \\
\text { Afonso et } \\
\text { al., } 2012 \\
{[112]}\end{array}$ \\
\hline
\end{tabular}

In conclusion, it is suggested that the $\mathrm{CO}_{2}$ is the most suitable laser for increasing the enamel resistance to acid in pits and fissures. The high temperatures achieved with these equipments also vaporize debris and biofilm [113] that may be present in the pits and fissures, thus cleaning these sites.

\section{Final carious tissue removal}

Several studies have been conducted on the effects of laser in dental mineralized tissues and developments in research continue to review new techniques and parameters for the treatment of tooth surfaces with different laser wavelengths. In this context, the application of this new technology in the selective removal of decayed tissue and on tooth surface preparation for adhesive restorative procedures, have brought promising results within the current philosophy of minimally invasive treatments.

Among the various wavelengths, lasers Er: YAG and Er, Cr: YSGG stand out as for the mechanism of action, that is associated with the phenomenon of the ablation process in which the incident laser beam is absorbed by water molecules present in dental tissue, causing rapid heating and evaporation of the same, being followed by successive microexplosions with ejection of the mineral tissue $[10,13.23]$. Thus, it is possible to use erbium lasers in conservative cavity preparations $[10,11,114]$ and the selective removal of caries [115].

In vitro studies have also been conducted to elucidate the high intensity lasers on carious tissue removal. Rizcalla et al., (2012) [116] have evaluated the influence of air pressure, water flow rate, and pulse frequency on the removal speed of enamel and dentin as well as on their surface morphology. Irradiation at $25 \mathrm{~Hz}$ for enamel and $30 \mathrm{~Hz}$ for dentin provided the best ablation rates within this study, but efficiency decreased if the frequency was raised further. Greater tissue ablation was found with water flow rate set to low and dropped with higher values. Fine-tuning of all parameters to get a good ablation rate with minimum surface damage seems to be key in achieving optimal efficiency for cavity preparation with an Er:YAG laser. Another in vitro study [117] have evaluated the extent of microleakage in cavities prepared with bur and Er:YAG laser, hybridized with different bonding systems. The cavities were prepared with bur or with laser parameters of $250 \mathrm{~mJ}, 4 \mathrm{~Hz}, 80.6 \mathrm{~J} / \mathrm{cm}^{2}$; the cavities were restored with a micro-hybrid composite resin using either with AdheSE or Clearfil SE Bond as adhesive system. The results have confirmed the 
Er:YAG laser to be as effective as the conventional methods for preparing adhesive restorations.

Clinical studies [118] have evaluated the effect on cavity preparation time, the pulse changes and the patient's subjective experience during removal of healthy tooth substance with high-speed bur and Er:YAG laser in thirty-five 14 to 18 -year-old patients. After local anaesthesia, Er:YAG laser and highspeed diamond bur were used for a $2 \mathrm{~mm}$ deep cavity preparation on the middle of the buccal surface on contra-lateral healthy maxillary first premolars. Laser ablation caused unpleasant smell and longer cavity preparation time, but was preferred by a majority of the adolescents. Hadley et al. (2000) [119] have randomly selected subjects for cavity preparation with conventional air turbine/bur dental surgery or an Er,Cr:YSGG laser-powered system using a splitmouth design. They prepared Class I, III and V cavities, placed resin restorations and evaluated sixtyseven subjects on the day of the procedure, 30 days and six months postoperatively for pulp vitality, recurrent caries, pain and discomfort and restoration retention. There were no statistical differences between the two treatment groups. The Er,Cr:YSGG laser system was effective for preparation of Class I, III and V cavities and resin restorations were retained by lased tooth surfaces.

Regarding the clinical use of erbium lasers for caries removal, some authors have reported that the treatment performed with the laser technique can be considered efficient and feasible in daily practice, without prejudice to the pulp tissues and with great acceptance by patients due to reduction of vibration, noise, reduction of pain sensitivity and, in some cases, no need for using anesthetics [36,37].

\section{Microbial reduction in carious tissue- antimicrobial photodynamic therapy}

Antimicrobial photodynamic therapy is a technique that consists of the use of photosensitive agents associated with a light source that is able to reduce the microflora associated with dental caries. The use of hand or rotary instruments does not guarantee the cleanliness of the infected dentin and residual bacteria that are normally present in the cavity before the restorative procedure [120]. Therefore, this treatment can be recommended for teeth with deep caries and reversible pulp inflammation, provided that the tooth is restored with a good marginal sealing.

The antimicrobial photodynamic therapy involves the use of photosensitive agents that are activated by a light source with a wavelength specific to generate cytotoxic species, including singlet oxygen and free radicals [121]. These products can damage critical components of cells or modify the metabolic activity irreversibly and may result in bacterial killing $[122,123]$. This mechanism of action avoids the development of bacterial resistance, since this is a limitation of conventional antimicrobials [124].

In vitro studies have already demonstrated that the most cariogenic microorganism group, the Streptocuccus mutans, may be removed under conditions similar to those found in a caries lesion [125]. It was also verified the ability of this therapy to eliminate bacteria embedded in collagen matrix in carious dentin in bovine and human carious dentin in vitro [126-128].

In vivo studies conducted on ex vivo carious dentin using ortho-toluidine blue and red LED light source $(\lambda=630 \mathrm{~nm})\left(47\right.$ or $\left.94 \mathrm{~J} / \mathrm{cm}^{2}\right)$ found that this therapy was effective in reducing microorganisms present in carious lesions produced in situ [129]. Another study was performed, in vivo [130], in 26 adult patients with deep carious lesions in permanent molars using methylene blue as a photosensitive agent and red low power laser (InGaAIP, $\lambda=660 \mathrm{~nm}, 100 \mathrm{~mW}, 320 \mathrm{~J} /$ $\left.\mathrm{cm}^{2}, 90 \mathrm{~s}, 9 \mathrm{~J}\right)$. The authors have also evidenced reduced cariogenic microorganisms in the carious dentin after treatment.

Antimicrobial photodynamic therapy is an important technique and may decrease risk of pulp exposure, resulting in a less traumatic treatment for patients. However, further studies are necessary to investigate new associations between photosensitive agents and various light sources, both in deciduous or permanent teeth.

\section{Miths}

\section{Prosthetic preparations in Dentistry}

Extensive prosthetic preparations, for example, metal-ceramic crowns, veneer, onlays, crowns and laminates free or not from metal are not a reality with the use of high power lasers. This happens because these types of preparations require meticulous level of details such as expulsive walls, suitable angle of the endings, depending on the type of material of choice for crowns and still smoothness and polish of the surface properly prepared to receive the settlement part, either with cement or adhesive system. The high power lasers, as already mentioned earlier in this article, operate associated with the phenomenon of 
the ablation process in which the incident laser beam is absorbed by water molecules present in dental tissue, causing rapid heating and evaporation of the same, being followed by successive microexplosions with ejection of the mineral tissue. In this process, using the available lasers, there is no way of carefully controlling the amount of tissue or the cavity boundaries eliminated. This way, it is still hard to perform ideal preparations for crowns or laminates with high power lasers.

However, there has been a great technological development in the field of high power lasers, especially $\mathrm{CO}_{2}$ laser prototypes with wavelength of $9.6 \mu \mathrm{m}$ and also ultrashort pulsed lasers (see more details in the section "Dental cavities prepared with ultrashort pulsed lasers") that are being considered promising for the future of preparations for cosmetic dentistry.

\section{Extensive caries removal and traditional cavity preparations in Dentistry}

Basically, for the same reasons explained above for the preparations of prosthetic crowns, the conventional cavity preparations with angled walls or sharp edges are hard to be performed with high power lasers. The highest percentage of caries removal is still performed by traditional methods, such as rotary instruments (tungsten - carbide) and extremely sharp curettes; however, the final removal of decayed tissue, near the pulp, can be removed with high power lasers, by ablation of the carious tissue and subsequent microbial reduction, currently associated with photodynamic therapy with low-power lasers and LED. Although many of these procedures are performed by traditional methods, the final removal of carious tissue with lasers represents a step forward, because they are able to strictly remove the damaged tissue, being very conservative, and also, with the advantage of promoting microbial reduction. This extremely conservative binomial - caries removal and microbial reduction, when applied using correct protocols that do not cause heating of the pulp above the tolerance limits, is already a reality for the conservative and restorative dentistry.

The restorative dentistry walks to minimally invasive procedures. The traditional cavity preparations for current generations, who already benefit of water fluoridation, are increasingly conservative. We arrive in a future where the removal of small spots of caries and the use of any technique for adhesive restorations will be widely used.

\section{FUtURE PERSPECTIVES}

\section{Dental cavities prepared with ultrashort pulsed lasers}

The interaction of lasers with biological tissues depends not only on the affinity between chromophore and wavelength, but also on the irradiation parameters used. The influence of these parameters on the ablation process with high power lasers is well known. Recently, the effect of pulse duration on this interaction has been studied.

Lasers currently available for cavity preparation have pulse duration in the order of microseconds. Even when the thermal relaxation time of dental tissues is considered, residual temperature increase may occur, causing undesirable thermal changes in underlying structures [35,131-133]. Studies evaluating the effect of pulse duration on the ablation process indicate that for short pulses, not only the energy necessary for the occurrence of ablation decreases, but the improvement of the ablation process is also observed due to rapid ablation of tissue irradiated [134]. This fact is attributed to the reduction of residual thermal damage due to the minimization of heat diffusion.

The ultrashort pulsed lasers emit photons with pulse durations in the order of pico and femtoseconds $(1 \mathrm{ps}=1 \times 10-12 \mathrm{~s}$ e $1 \mathrm{fs}=1 \times 10-15 \mathrm{~s})$. Dental hard tissue ablation with longer pulses (microseconds) is based on thermomechanical mechanisms, while shorter laser pulses (pico and femtoseconds) are based on non-thermal ablation mechanisms [135]. The reduction of thermal damage to dental substrates with the ultrashort pulsed lasers is based precisely on this aspect of non-thermal ablation process. The irradiated material is ejected rapidly, and consumes most of the absorbed energy. Therefore, efficient ablation is achieved without obtaining significant residual heat, avoiding thermal and mechanical damage to the remaining material [136]. The use of ultrashort pulses reduces ablation threshold, requiring less energy to remove the substrate, and resulting in less volume of heated material [137-140].

The effect of ultrashort pulsed lasers on dental substrates results in patterns that indicate the absence of damages to adjacent tissues and precise removal of dental tissue [136,138,140]. Cavities prepared with picosecond and femtosecond lasers are welldefined [140-143]. The surface morphology varies according to irradiation parameters used. Either areas of melted and solidified dentin and enamel or rough surfaces without melting or carbonization can 
be observed $[140,144]$. To date, there are no reports in the literature of clinical use of ultrashort pulsed lasers in the oral cavity. Its use is already common in ophthalmology and vascular surgeries, and several studies with different wavelengths and pulse duration have been conducted in enamel and dentin. However, much still needs to be studied so that these lasers will become a reality in clinical dentistry.

\section{Conclusions}

High and low intensity lasers have been used for a long time in many procedures in dentistry. Low intensity lasers can bring several benefits to restorative dentistry such as satisfactory outcome in the control and maintenance of a healthy gingiva, after cavity preparation to prevent post-operative sensitivity and using the antimicrobial photodynamic therapy, an important technique to promote microbial reduction, mainly in carious tissues.

Based on the published studies, the $\mathrm{CO}_{2}$, a high intensity laser, when applied with the correct protocol may be a promising tool in the prevention of tooth erosive wear and also for increasing the enamel resistance to acid in pits and fissures. The high temperatures achieved with these equipments also vaporize debris and biofilm that may be present in the pits and fissures, thus cleaning these sites. The erbium lasers can be used for final caries removal, without prejudice to the pulp tissues and with great acceptance by patients due to reduction of vibration, noise, reduction of pain sensitivity and, in some cases, no need for using anesthetics

There is always an evolution regarding the techniques and procedures of traditional dentistry. The most important thing is to associate the technological innovations of dentistry to traditional procedures. The key to success for the future is to associate both clinical procedures and innovations, based on evidences and research published in journals with high impact factors, which have strict protocols and can be used in clinical practice. New technology always brings the fears of its use. The goal is to gain scientific knowledge that can support the appropriate use of these technologies, which can bring benefits to patients.

It is still not a reality to perform traditional prosthetic preparations, total removal of caries, as the most significant examples. However, recent researches with $\mathrm{CO}_{2}$ lasers of $9.6 \mu \mathrm{m}$ and ultrashort pulsed lasers contribute to future procedures in the area of clinical dentistry.

\section{ACKNOWLegments}

The authors would like to thank the Restorative Dentistry Department of the School of Dentistry - University of São Paulo, São Paulo, Brazil and FAPESP grants n. 2010/07212-5 and 2011/08392-0 for their support in the accomplishment of this study.

\section{References}

1. Baxter G. Therapeutic lasers: theory and practice. London: Churchill Livingstone; 1997.

2. Karu T. Photobiological fundamentals of low-power laser therapy. IEEE J Quantum Elect. 1987;23(10):1703-19.

3. Karu T. photobiology of low-power laser effects. Health Phys. 1989;56(5):691-704.

4. Gonçalves SE, de Araujo MA, Damião AJ. Dentin bond strength: influence of laser irradiation, acid etching, and hypermineralization. J Clin Laser Med Surg. 1999;17(2):7785.

5. Matos $\mathrm{AB}$, Oliveira DC, Kuramoto $\mathrm{M}$ Jr, Eduardo $\mathrm{CP}$, Matson E. Nd:YAG laser influence on sound dentin bond strength. J Clin Laser Med Surg. 1999;17(4):165-9.

6. Eduardo Cde P, Bello-Silva MS, Moretto SG, Cesar PF, de Freitas PM. Microtensile bond strength of composite resin to glass-infiltrated alumina composite conditioned with Er,Cr:YSGG laser. Lasers Med Sci 2012;27(1):7-14.

7. Qadri T, Miranda L, Tuner J, Gustafsson A: The shortterm effects of low-level lasers as adjunct therapy in the treatment of periodontal inflammation. J Clin Periodontol. 2005;32(7):714-9.

8. Pejcic A, Grujicic D: [low-power laser therapy in the treatment

of parodontopathy]. Vojnosanit Pregl. 2007;64(12):845-50.

9. Pejcic A, Kojovic D, Kesic L, Obradovic R: The effects of low level laser irradiation on gingival inflammation. Photomed Laser Surg. 2010;28(1):69-74.

10. Hibst R, Keller U. Experimental studies of the application of the Er:YAG laser on dental hard substances: I. Measurement of the ablation rate. Lasers Surg Med. 1989;9(4):338-44.

11. Apel C, Meister J, Ioana RS, Franzen R, Hering P, Gutknecht N. The ablation threshold of Er:YAG and Er:YSGG laser radiation in dental enamel. Lasers Med Sci. 2002;17(4):24652 .

12. Cozean C, Arcoria CJ, Pelagalli J, Powell GL. Dentistry for the 21 st century? Erbium:YAG laser for teeth. J Am Dent Assoc. 1997 Aug:128(8):1080-7.

13. Gutknecht N, Eduardo CP. A odontologia e o laser: atuação do laser na especialidade odontológica. São Paulo: Quintessence; 2004.

14. Gouw-Soares S, Stabholz A, Lage-Marques JL, Zezell DM, Groth EB, Eduard CP. Comparative study of dentine permeability after apicectomy and surface treatment with 9.6 mu $\mathrm{m}$ TEA $\mathrm{CO}_{2}$ and Er : YAG laser irradiation. J Clin Laser Med Sur. 2004 Apr;22(2):129-39.

15. Fan K, Bell P, Fried D. Rapid and conservative ablation and modification of enamel, dentin, and alveolar bone using a 
high repetition rate transverse excited atmospheric pressure $\mathrm{CO}_{2}$ laser operating at lambda $=9.3$ micro. J Biomed Opt. 2006 Nov-Dec;11(6):064008.

16. Nakamura $\mathrm{Y}$, Hossain M, Yamada Y, Masuda YM, Jayawardena JA, Matsumoto K. Basic study of morphological changes and surface roughness of cavities prepared by TEA $\mathrm{CO}_{2}$ laser irradiation. Photomed Laser Surg. 2006 Aug;24(4):503-7.

17. Fried D, Zuerlein MJ, Le CQ, Featherstone JD. Thermal and chemical modification of dentin by $9-11$-microm $\mathrm{CO}_{2}$ laser pulses of 5-100-micros duration. Lasers Surg Med. 2002;31(4):275-82.

18. Frentzen M, Winkelstrater C, van Benthem H, Koort HJ. The effects of pulsed ultraviolet and infra-red lasers on dental enamel. Eur J Prosthodont Restor Dent. 1996 Sep;4(3):99104.

19. Li ZZ, Code JE, Van De Merwe WP. Er:YAG laser ablation of enamel and dentin of human teeth: determination of ablation rates at various fluences and pulse repetition rates. Lasers Surg Med. 1992;12(6):625-30.

20. de Souza-Gabriel AE, Chinelatti MA, Borsatto MC, Pecora JD, Palma-Dibb RG, Corona SA. Effect of Er:YAG laser irradiation distance on superficial dentin morphology. Am J Dent. 2006 Aug;19(4):217-21.

21. Delme KI, De Moor RJ. Scanning electron microscopic evaluation of enamel and dentin surfaces after Er:YAG laser preparation and laser conditioning. Photomed Laser Surg. 2007 Oct;25(5):393-401.

22. Freitas PM, Navarro RS, Barros JA, de Paula Eduardo C. The use of Er:YAG laser for cavity preparation: an SEM evaluation. Microsc Res Tech. 2007;70(9):803-8.

23. Gutknecht N, Esteves-Oliveira M. Lasers for hard tissue, cavity preparation and caries removal. In: N. Gutknecht, editor Proceedings of the 1st International Workshop of Evidence Based Dentistry on Lasers in Dentistry: Quintessence Publishing; 2007.

24. Yu DG, Kimura Y, Kinoshita J, Matsumoto K. Morphological and atomic analytical studies on enamel and dentin irradiated by an erbium, chromium:YSGG laser. J Clin Laser Med Surg. 2000 Jun;18(3):139-43.

25. Bader C, Krejci I. Indications and limitations of Er:YAG laser applications in dentistry. Am J Dent. 2006 Jun;19(3):178-86.

26. Bispo LB. Condicionamento do esmalte com Er:YAG laser e ácido fosfórico: resistência à tração e microscopia eletrônica de varredura São Paulo: Faculdade de Odontologia da Universidade de São Paulo; 2000

27. Esteves-Oliveira M, Zezell DM, Apel C, Turbino ML, Aranha AC, Eduardo Cde P, Gutknecht N. Bond strength of selfetching primer to bur cut, Er,Cr:YSGG, and Er:YAG lased dental surfaces. Photomed Laser Surg. 2007 Oct;25(5):37380.

28. Svizero NR, Carvalho RS, Domingues LA, Pegoraro CN, Francischone CE, Rocha MC. Shear bond strength of resin composite to enamel treated with Er:YAG laser and phosphoric acid. Braz Dent Sci. 2007;10(4):13-18.

29. Barbosa CS, Nicoló R, Araújo MAM, Araújo RM. Er:YAG laser or high speed turbine: comparative study of the sealament of direct restorations. Braz Dent Sci. 2008;11(3):32-37.

30. Amaral F, Colucci V, Souza-Gabriel AE, Chinelatti MA, Palma-Dibb RG, Corona SA. Bond durability in erbium:yttrium-aluminum-garnet laser-irradiated enamel. Lasers Med Sci. 2010;25(2):155-63.

31. Eduardo CP, Bello-Silva MS, Ramalho KM, Lopes RMG,
Freitas PM. Laser assisted re-established of canine guidance: esthetic and functional reconstruction of worn canines. Int Mag Laser Dent. 2009;2:16-9.

32. Bertrand MF, Hessleyer D, Muller-Bolla M, Nammour S, Rocca JP. Scanning electron microscopic evaluation of resindentin interface after Er:YAG laser preparation. Lasers Surg Med. 2004;35(1):51-7.

33. Aranha AC, De Paula Eduardo C, Gutknecht N, Marques MM, Ramalho KM, Apel C. Analysis of the interfacial micromorphology of adhesive systems in cavities prepared with Er,Cr:YSGG, Er:YAG laser and bur. Microsc Res Tech. 2007 Aug;70(8):745-51.

34. Moretto SG, Azambuja N, Jr., Arana-Chavez VE, Reis AF, Giannini M,EduardoCdeP, etal.Effects of ultramorphological changes on adhesion to lased dentin-Scanning electron microscopy and transmission electron microscopy analysis. Microsc Res Tech. 2011 Aug;74(8):720-6.

35. Ceballo L, Toledano M, Osorio R, Tay FR, Marshall GW. Bonding to Er-YAG-laser-treated dentin. J Dent Res. 2002 Feb;81(2):119-22.

36. Keller U, Hibst R, Geurtsen W, Schilke R, Heidemann D, Klaiber B, Raab WH. Erbium:YAG laser application in caries therapy. Evaluation of patient perception and acceptance. $\mathrm{J}$ Dent. 1998;26(8):649-56.

37. Matsumoto K, Hossain M, Hossain MM, Kawano H, Kimura Y. Clinical assessment of Er,Cr:YSGG laser application for cavity preparation. J Clin Laser Med Surg. 2002;20(1):1721.

38. Freitas PM, Ramos TM, Ramos TM, Moretto SG, Lago ADN. Benefícios dos lasers de alta e baixa potência no procedimento restaurador direto: relato de caso. Revista da Assoc Paul Cirur Dent. 2011;65(6):462-6.

39. Blay CC. Análise comparativa da redução bacteriana com irradiação do laser de Er:YAG ou ponta montada em alta rotação após remoção de tecido cariado em dentina: estudo in anima móbile São Paulo: Universidade de São Paulo; 2001.

40. Shimizu N, Yamaguchi M, Goseki T, Shibata Y, Takiguchi $\mathrm{H}$, Iwasawa $\mathrm{T}$, et al. Inhibition of prostaglandin e2 and interleukin 1-beta production by low-power laser irradiation in stretched human periodontal ligament cells. J Dent Res. 1995;74(7):1382-8.

41. Tuner J, Hode L. It's all in the parameters: a critical analysis of some well-known negative studies on low-level laser therapy. J Clin Laser Med Surg. 1998;16(5):245-8.

42. Tam G. Low power laser therapy and analgesic action. J Clin Laser Med Surg. 1999;17:29-33.

43. Sakurai Y, Yamaguchi M, Abiko Y. Inhibitory effect of low-level laser irradiation on lps-stimulated prostaglandin e2 production and cyclooxygenase-2 in human gingival fibroblasts. Eur J Oral Sci. 2000;108(1):29-34.

44. Moore P, Ridgway TD, Higbee RG, Howard EW, Lucroy MD: Effect of wavelength on low-intensity laser irradiationstimulated cell proliferation in vitro. Lasers Surg Med. 2005;36(1):8-12.

45. Eduardo $\mathrm{C}$. The influence of erbium:yttrium-aluminumgarnet laser ablation with variable pulse width on morphology and microleakage of composite restorations. Lasers Med Sci. 2010;25(6):881-9.

46. Lins RDAU, Lucena KCR, Granville-Garcia AF, Dantas EM, Catão MHCV, Neto LGC. Bioestimulation effects of low-power laser in the repair process. An Bras Dermarol. 2010;85(6):849-55. 
47. Walsh LJ. The current status of low level laser therapy in dentistry. Part 2. Hard tissue applications. Aust Dent J. 1997;42(5):302-6.

48. Almeida-Lopes L, Rigau J, Zangaro RA, Guidugli-Neto J, Jaeger MM: Comparison of the low level laser therapy effects on cultured human gingival fibroblasts proliferation using different irradiance and same fluence. Lasers Surg Med. 2001;29(2):179-84.

49. Pereira AN, Eduardo Cde P, Matson E, Marques MM: Effect of low-power laser irradiation on cell growth and procollagen synthesis of cultured fibroblasts. Lasers Surg Med. 2002;31(4):263-7.

50. Azevedo LH, de Paula Eduardo F, Moreira MS, de Paula Eduardo C, Marques MM: Influence of different power densities of lilt on cultured human fibroblast growth : a pilot study. Lasers Med Sci. 2006;21(2):86-9.

51. Saygun I, Karacay S, Serdar M, Ural AU, Sencimen M, Kurtis B: Effects of laser irradiation on the release of basic fibroblast growth factor (bfgf), insulin like growth factor-1 (igf-1), and receptor of igf-1 (igfbp3) from gingival fibroblasts. Lasers Med Sci. 2008;23(2):211-5.

52. Pourreau-Schneider N, Ahmed A, Soudry M, Jacquemier J, Kopp F, Franquin JC, Martin PM: Helium-neon laser treatment transforms fibroblasts into myofibroblasts. Am J Pathol. 1990;137(1):171-8.

53. Salate AC, Barbosa G, Gaspar P, Koeke PU, Parizotto NA, Benze BG, et al. Effect of in-ga-al-p diode laser irradiation on angiogenesis in partial ruptures of achilles tendon in rats. Photomed Laser Surg. 2005;23(5):470-5.

54. Murray PE, About I, Lumley PJ, Franquin JC, Remusat M, Smith AJ. Human odontoblast cell numbers after dental injury. J Dent. 2000;28(4):277-85.

55. Godoy BM, Arana-Chavez VE, Nunez SC, Ribeiro MS. Effects of low-power red laser on dentine-pulp interface after cavity preparation. An ultrastructural study. Arch Oral Biol. 2007;52(9):899-903.

56. Eduardo CP, Rocha RG, Ramalho KM: The use of low level laser after cavity preparation in vital tooth: a clinical report. J Leban Dent Assoc 2010;46:57-60.

57. Loewenstein WR, Rathkamp R:Astudy on the pressoreceptive sensibility of the tooth. J Dent Res. 1955;34(2):287-94.

58. Fearnhead RW: Histological evidence for the innervation of human dentine. J Anat. 1957;91(2):267-77.

59. Brannstrom M: Sensitivity of dentine. Oral Surg Oral Med Oral Pathol. 1966;21(4):517-26.

60. Ferreira AN, Silveira L, Genovese WJ, de Araujo VC, Frigo L, de Mesquita RA, et al. Effect of gaaias laser on reactional dentinogenesis induction in human teeth. Photomed Laser Surg. 2006;24(3):358-65.

61. Nomura K, Yamaguchi M, Abiko Y. Inhibition of interleukin1beta production and gene expression in human gingival fibroblasts by low-energy laser irradiation. Lasers Med Sci. 2001;16(3):218-23.

62. Laakso EL, Cabot PJ: Nociceptive scores and endorphincontaining cells reduced by low-level laser therapy (LLLT) in inflamed paws of wistar rat. Photomed Laser Surg. 2005;23(1):32-5.

63. Hagiwara S, Iwasaka H, Okuda K, Noguchi T. Gaalas (830 $\mathrm{nm}$ ) low-level laser enhances peripheral endogenous opioid analgesia in rats. Lasers Surg Med. 2007;39(10):797-802.

64. Tagliaferro EP, Rodrigues LK, Nobre Dos Santos M, Soares LE, Martin AA: Combined effects of carbon dioxide laser and fluoride on demineralized primary enamel: An in vitro study. Caries Res. 2007;41(1):74-6.

65. Zero DT, Lussi A. Erosion--chemical and biological factors of importance to the dental practitioner. Int Dent J. 2005;55(4 Suppl 1):285-90.

66. Zero DT, Lussi A. Etiology of enamel erosion - intrinsic and extrinsic factors. In:M. Addy, M. Embery, G. Edgar, M. Orchardson R. Tooth wear and sensitivity.London, Martin Dunitz; 2000.

67. Calvadini C, Siega-Riz AM, Popkin BM: Us adolescent food intake trends from 1965 - 1996. Archs Dis Child. 2000;83(1):18-24.

68. Lussi A, Schaffner M: Progression of and risk factors for dental erosion and wedge-shaped defects over a 6-year period. Caries Res. 2000;3(2)4:182-7.

69. Aranha AC, Eduardo Cde P, Cordas TA. Eating disorders part II: clinical strategies for dental treatment. J Contemp Dent Pract. 2008a;9(7):89-96.

70. Aranha AC, Eduardo Cde P, Cordas TA. Eating disorders. Part I: psychiatric diagnosis and dental implications. J Contemp Dent Pract. 2008b;9(6):73-81.

71. Lussi A, Hellwig E. Risk assessment and preventive measures. Monogr Oral Sci. 2006;20:190-9.

72. Amaechi BT, Higham SM. Dental erosion: possible approaches to prevention and control. J Dent. 2005;33(3):24352 .

73. Turssi CP, Hara AT, Domiciano SJ, Serra MC. Study on the potential inhibition of root dentine wear adjacent to fluoride-containing restorations. J Mater Sci Mater Med. 2008;19(1):47-51.

74. Stern RH, Sognnaes RF. Laser inhibition of dental caries suggested by first tests in vivo. J Am Dent Assoc. 1972;85(5):1087-90.

75. Vlacic J, Meyers IA, Walsh LJ. Laser-activated fluoride treatment of enamel as prevention against erosion. Aust Dent J. 2007;52(3):175-80.

76. Magalhaes AC, Rios D, Machado MA, Da Silva SM, Lizarelli Rde F, Bagnato VS, Buzalaf MA. Effect of nd:Yag irradiation and fluoride application on dentine resistance to erosion in vitro. Photomed Laser Surg. 2008;26(6):559-63.

77. Rios D, Magalhaes AC, Machado MA, da Silva SM, Lizarelli Rde F, Bagnato VS, et al. In vitro evaluation of enamel erosion after nd:Yag laser irradiation and fluoride application. Photomed Laser Surg. 2009;27(5):743-7.

78. Sobral MA, Lachowski KM, de Rossi W, Braga SR, Ramalho KM. Effect of nd:Yag laser and acidulated phosphate fluoride on bovine and human enamel submitted to erosion/abrasion or erosion only: An in vitro preliminary study. Photomed Laser Surg. 2009;27(5):709-13.

79. Magalhaes AC, Romanelli AC, Rios D, Comar LP, Navarro RS, Grizzo LT, Aranha AC, et al. Effect of a single application of tif4 and naf varnishes and solutions combined with nd:Yag laser irradiation on enamel erosion in vitro. Photomed Laser Surg. 2011;29(8):537-44.

80. Fox JL, Yu D, Otsuka M, Higuchi WI, Wong J, Powell GL. Initial dissolution rate studies on dental enamel after $\mathrm{CO}_{2}$ laser irradiation. J Dent Res. 1992;71(7):1389-98.

81. Fried D, Glena RE, Featherstone JD, Seka W. Permanent and transient changes in the reflectance of $\mathrm{CO}_{2}$ laser-irradiated dental hard tissues at lambda $=9.3,9.6,10.3$, and 10.6 microns and at fluences of $1-20 \mathrm{j} / \mathrm{cm}^{2}$. Lasers Surg Med. 1997;20(1):22-31.

82. Featherstone JD, Barrett-Vespone NA, Fried D, Kantorowitz $\mathrm{Z}$, Seka W. $\mathrm{CO}_{2}$ laser inhibitor of artificial caries-like lesion 
progression in dental enamel. J Dent Res. 1998;77(6):1397403.

83. Esteves-Oliveira M, Apel C, Gutknecht N, Vellosos Jr WF, Cotrin MEB, Eduardo $\mathrm{CP}$, et al. Low fluence $\mathrm{CO}_{2}$ laser irradiation decreases enamel solubility. Laser Physics. 2008;18:478-85.

84. Esteves-Oliveira M, Eduardo CP, Lampert F, Apel C. Changes in dental enamel birefringence after $\mathrm{CO}_{2}$ laser irradiation through fluoride gel - a pilot study. Berlin: Heidelberg, Springer-Verlag;2008.

85. Steiner-Oliveira C, Nobre-dos-Santos M, Zero DT, Eckert $\mathrm{G}$, Hara AT. Effect of a pulsed $\mathrm{CO}_{2}$ laser and fluoride on the prevention of enamel and dentine erosion. Arch Oral Biol. 2010;55(2):127-33

86. Wiegand A, Magalhaes AC, Navarro RS, Schmidlin PR, Rios D, Buzalaf MA, et al. Effect of titanium tetrafluoride and amine fluoride treatment combined with carbon dioxide laser irradiation on enamel and dentin erosion. Photomed Laser Surg. 2010;28(2):219-26.

87. Wegehaupt FJ, Sener B, Attin T, Schmidlin PR: Antierosive potential of amine fluoride, cerium chloride and laser irradiation application on dentine. Arch Oral Biol. 2011;56(12):1541-7.

88. Esteves-Oliveira M, Yu H, de Paula Eduardo C, Meister J, Lampert F, Attin T, et al. Screening of $\mathrm{CO}_{2}$ laser (10.6 mum) parameters for prevention of enamel erosion. Photomed Laser Surg. 2012;30(6):331-8.

89. Esteves-Oliveira M, Pasaporti C, Heussen N, Eduardo CP, Lampert F, Apel C. Rehardening of acid-softened enamel and prevention of enamel softening through $\mathrm{CO}_{2}$ laser irradiation. J Dent. 2011;39(6):414-21.

90. Esteves-Oliveira M, Pasaporti C, Heussen N, Eduardo CP, Lampert F, Apel C. Prevention of toothbrushing abrasion of acid-softened enamel by $\mathrm{CO}_{2}$ laser irradiation. J Dent 2011;39(9):604-11.

91. Ramalho KM, de Paula Eduardo C, Heussen N, Rocha RG, Lampert F, Apel C, et al. Protective effect of $\mathrm{CO}_{2}$ laser (10.6 $\mu \mathrm{m})$ and fluoride on enamel erosion in vitro. Lasers Med Sci. 2012.[Epub ahead of print]

92. Ramalho KM. Prevenção da erosão em esmalte dental irradiado com laser de $\mathrm{CO}_{2}$ : estudo in situ. São Paulo: Universidade de São Paulo; 2010.

93. American Dental Association. Dental sealants - ADA Council on Access, Prevention and Interprofessional Relations; ADA Council on Scientific Affair. J Am Dent Assoc. 1997;128,(4):485-8.

94. Fejerskov O, Thylstrup A. Dental enamel. In: Mjor , Fejerskov O, editors. Human oral embryology. Copenhagen: Blackwell Munksgaard; 1986. p. 50-89.

95. Nowak A, Crall J. Pediatric dentistry: infancy through adolescence. 2nd ed. Philadelphia: W.B. Saunders; 1994. p. 445-50.

96. Pearce E, Larsen M, Coote G. Fluoride in enamel lining pits and fissures of the occlusal groove-fossa system in human molar teeth. Caries Res. 1999;33(3):196-205.

97. Kato J, Moriya K, Jayawardena JA, Wijeyeweera RL, Awazu K. Prevention of dental caries in partially erupted permanent teeth with a $\mathrm{CO}_{2}$ laser. J Clin Laser Med Surg. 2003;21(6):369-74.

98. Gouw-Soares S, Gutknecht N, Conrads G, Lampert F, Matson E,Eduardo CP. The bactericidal effect of Ho:YAG laser irradiation within contaminated root dentinal samples. J Clin Laser Med Surg. 2000;18(2):81-7.
99. Silva FC, Freitas LR, Lourenço APA, Braga-Junior AC, Jorge AO, Oliveira LD, et al. Analysis of the effectiveness of the instrumentation associated to antimicrobial photodynamic therapy and root canal dressing in the elimination of Enterococcus faecalis in root canals. Braz Dent Sci. 2010;13(1/2):31-8.

100. Bahar A, Tagomori S. The effect of normal pulsed Nd-YAG laser irradiation on pits and fissures in human teeth. Caries Res. 1994;28(6):460-7.

101. Delbem AC, Cury JA, Nakassima CK, Gouveia VG, Theodoro LH. Effect of Er:YAG laser on CAF2 formation and its anticariogenic action on human enamel. An in vitro study. J Clin Laser Med Surg. 2003;21(4):197-201.

102. Fowler BO, Kuroda S. Changes in heated and in lased irradiated human tooth enamel and their probable effects on solubility. Calcif Tissue Int. 1986;38(4):97-208.

103. Steiner-Oliveira C, Rodrigues LK, Soares LE, Martin AA, Zezell DM, Nobre-dos-Santos M. Chemical, morphological and thermal effects of 10.6-microm $\mathrm{CO}_{2}$ laser on the inhibition of enamel demineralization. Dent Mater J. 2006;25(3):455-62.

104. Cecchini RCM, Zezel DM, Oliveira E, Freitas PM, Eduardo CP. Effect of Er:YAG laser on enamel acid resistance: Morphological and atomicspectrometry analysis. Laser Surg Med 2005;37(5):366-72.

105. Hossain M, Nakamura Y, Yamada Y, Ito M, Matsumoto K. Caries -preventive effect of Er:YAG laser irradiation with or without water mist. J Clin Laser Med Surg. 2000;18(2):61-5.

106. Walsh LJ, Perham SJ. Enamel fusion using a carbon dioxide laser: a technique for sealing pits and fissures. Clin Prev Dent. 1991;13(3):16-20.

107. Brugnera Júnior A, Rosso N, Duarte D, Pinto AC, Genovese $\mathrm{W}$. The use of carbon dioxide laser in pit and fissure caries prevention: clinical evaluation. J Clin Laser Med Surg. 1997;15(2):79-82.

108. Myaki SI, Watanabe IS, Eduardo Cde P, Issáo M. Nd:YAG laser effects on the occlusal surface of premolars. Am J Dent. 1998;11(3):103-5.

109. Matson JR, Matson E, Navarro RS, Bocangel JS, Jaeger RG, Eduardo CP. Er:YAG laser effects on enamel occlusal fissures: an in vitro study. J Clin Laser Med Surg. 2002;20(1):27-35.

110. Nobre dos Santos M, Fried D, Rapozo-HiloM, Featherstone JD. Effect of a new carbon dioxide laser and fluoride on occlusal caries progression in dental enamel. Lasers in Dentistry VIII. Proceedings of SPIE. 2002;4610:132-39.

111. Kato J, Moriya K, Jayawardena JA, Wijeyeweera RL, Awazu K. Prevention of dental caries in partially erupted permanent teeth with a $\mathrm{CO}_{2}$ laser. J Clin Laser Med Surg. 2003;21(6):369-74.

112. Correa-Afonso AM, Ciconne-Nogueira JC, Pécora JD, Palma-Dibb RG. In vitro assessment of laser efficiency for caries prevention in pits and fissures. Microsc Res Tech. 2012;75(2):245-52

113. Lopes AM, Jardim-Junior EG, Kina JR. Influence of irradiation of erbium:yag laser on microbial viability. Braz Dent Sci. 2004;7(1):75-83.

114. Navarro RS, Gouw-Soares S, Cassoni A, Haypek P, Zezell DM, de Paula Eduardo C. The influence of erbium:yttriumaluminum-garnet laser ablation with variable pulse width on morphology and microleakage of composite restorations. Lasers Med Sci. 2010;25(6):881-9.

115. Olivi G, Genovese MD, Caprioglio C. Evidence-based dentistry on laser paediatric dentistry: review and outlook. 
Eur J Paediatr Dent. 2009;10(1):29-40.

116. Rizcalla N, Bader C, Bortolotto T, Krejci I. Improving the efficiency of an Er:YAG laser on enamel and dentin. Quintessence Int. 2012;43(2):153-60.

117. Aranha AC, Turbino ML, Powell GL, Eduardo Cde P. Assessing microleakage of class $\mathrm{V}$ resin composite restorations after Er:YAG laser and bur preparation. Lasers Surg Med. 2005;37(2):172-7.

118. Mosskull Hjertton P, Bågesund M. Er:YAG laser or highspeed bur for cavity preparation in adolescents. Acta Odontol Scand. 2012. (In press).

119. Hadley J, Young DA, Eversole LR, Gornbein JA. A laserpowered hydrokinetic system for caries removal and cavity preparation. J Am Dent Assoc. 2000;131(6):777-85.

120. Mertz-Fairhurst EJ, Curtis JW Jr., Ergle JW, Rueggeberg FA, Adair SM. Ultraconservative and cariostatic sealed restorations: results at year 10. J Am Dent Assoc. 1998;129(1):55-66.

121. Dougherty TJ, Gomer CJ, Henderson BH, Jori G, Kessel D, Korbelik M, et al. Photodynamic therapy. J Natl Cancer Inst 1998;90(12):889-905.

122. Castano AP, Demidova TN, Hamblin MR. Mechanisms in photodynamic therapy: part one-photosensitizers, photochemistry and cellular localization. Photodiagnosi Photodyn Ther. 2004;1(4):279-93;

123. Akilov OE, Kosaka S, O'Riordan K, Song X, Sherwood M, Flotte TJ, et al. The role of photosensitizer molecular charge and structure on the efficacy of photodynamic therapy against Leishmania parasites Chem Biol. 2006;13(8):839-47.

124. Wilson M. Lethal photosensitisation of oral bacteria and its potential application in the photodynamic therapy of oral infections. Photochem Photobiol Sci. 2004;3(5):412-8.

125. Burns T, Wilson M, Pearson GJ. Effect of dentine and collagen on the lethal photosensitization of Streptococcus mutans. Caries Res. 1995;29(3):192-7.

126. de Melo MAS, de Paula DM, Lima JPM, Borges FMC, Steiner-Oliveira $\mathrm{C}$, Barros $\mathrm{EB}$, et al. In vitro assessment of thermal changes in human teeth during photodynamic antimicrobial chemotherapy performed with red light sources. Laser Physics. 2010;20(6):1504-13.

127. Stringer GJ, Bird PS, Walsh LJ. Lethal laser photosensitization of Streptococcus mutans with a visible red diode laser. Aust Dent J. 2000;45(22);

128. Williams JA, Pearson GJ, Colles MJ, Wilson M. The photoactivated antibacterial action of toluidine blue $\mathrm{O}$ in a collagen matrix and in carious dentine. Caries Res. 2004;38(6):530-6.

129. Lima JPM, De Melo MAS, Borges FMC, Teixeira AH, Steiner-Oliveira C, Nobre dos Santos M, et al. Evaluation of the antimicrobial effect of photodynamic antimicrobial therapy in an in situ model of dentine caries. Eur J Oral Sci. 2009;117(5):1-7.

130. Guglielmi Cde A, Simionato MR, Ramalho KM, Imparato JC, Pinheiro SL, Luz MA. Clinical use of photodynamic antimicrobial chemotherapy for the treatment of deep carious lesions. J Biomed Opt. 2011;16(8):088003. doi:10.1117/1.3611009.

131. Van Meerbeek B, De Munck J, Mattar D, Van Landuyt K, Lambrechts P. Microtensile bond strengths of an etch\&rinse and self-etch adhesive to enamel and dentin as a function of surface treatment. Oper Dent. 2003;28(5):647-60.

132. Cardoso MV, Coutinho E, Ermis RB, Poitevin A, Van Landuyt $\mathrm{K}$, et al. Influence of Er,Cr:YSGG laser treatment on the microtensile bond strength of adhesives to dentin. J
Adhes Dent. 2008a;10(1):25-33.

133. Cardoso MV, De Munck J, Coutinho E, Ermis RB, Van Landuyt K, de Carvalho RC, et al. Influence of Er,Cr:YSGG laser treatment on microtensile bond strength of adhesives to enamel. Oper Dent. 2008b;33(4):448-55.

134. Melcer J, Farcy JC, Hellas Gand Badiane M. Preparation of Cavities using a TEA $\mathrm{CO}_{2}$ laser.Preparation of cavities using a TEA $\mathrm{CO}_{2}$ laser. 3rd International Congress on Lasers in Dentistry, Salt Lake City; 1992.

135. Neev J, Lee JP. Two-lasers assisted ablation: a method for enhancing conventional laser ablation of materials. Lasers Surg Med. 1996;19(2):130-4.

136. Kim BM, Eichler J, Da Silva LB. Frequency doubling of ultrashort laser pulses in biological tissues. Appl Opt. 1999;38(34):7145-50.

137. Kimura Y, Wilder-Smith P, Arrastia-Jitosho AM, Liaw LH, Matsumoto K, Berns MW. Effects of nanosecond pulsed Nd: YAG laser irradiation on dentin resistance to artificial carieslike lesions. Lasers Surg Med. 1997;20(1):15-21.

138. Lizarelli RF, Kurachi C, Misoguti L, Bagnato VS. A comparative study of nanosecond and picosecond laser ablation in enamel: morphological aspects. J Clin Laser Med Surg. 2000;18(3):151-7.

139. Bello-Silva MS. Análise morfológica e da resistência adesiva dos tecidos dentais duros irradiados com lasers de pulsos ultracurtos. São Paulo: Universidade de São Paulo; 2010.

140. Bello-Silva MS, Wehner M, de Paula Eduardo C, Lampert F, Poprawe R, Hermans M, et al. Precise ablation of dental hard tissues with ultra-short pulsed lasers. Preliminary exploratory investigation on adequate laser parameters. Lasers Med Sci. 2012. In press.

141. Grad L, Mozina J. Laser pulse shape influence on optically induced dynamic processes. Appl Surf Sci. 1998;127-9.

142. Papadopoulos DN, Papagiakoumou E, Khabbaz MG, Makropoulou M, Serafetinides AA. Experimental study of Er:YAG laser ablation of hard dental tissue at various lasing parameters. 7th International Conference on Laser Ablation, COLA'03, Crete, Greece.

143. Nishimoto Y, Otsuki M, Yamauti M, Eguchi T, Sato Y, Foxton RM, et al. Effect of pulse duration of Er: YAG laser on dentin ablation. Dent Mater J. 2008 May;27(3):433-9.

144. Lizarelli RF, Kurachi C, Misoguti L, Bagnato VS. Characterization of enamel and dentin response to Nd:YAG picosecond laser ablation. J Clin Laser Med Surg. 1999;17(3):127-31.

Received: 2012 oct. 19 Accepted: 2012 oct. 31

\section{Corresponding author:}

Carlos de Paula Eduardo Faculdade de Odontologia da Universidade de São Paulo Laboratório Especial de Laser em Odontologia (LELO-USP). Av. Professor Lineu Prestes, 2227 - Cidade Universitária; 05508-000 - São Paulo - SP.

Email: cpeduard@usp.br 